УДК 93

ББК 63.3(2)522-6+63.3(5)

\title{
Причины и последствия заключения русско-кашгарского торгового договора 1872 г.
}

\author{
C.B. Moucees
}

Барнаульский юридический институт МВД России (Барнаул, Россия)

\section{Causes and Consequences of the Conclusion of the Russian-Kashgar Trade Agreement of 1872}

S.V. Moiseev

Barnaul Law Institute of the Ministry of Internal Affairs of Russia (Barnaul, Russia)

Взаимоотношения России и уйгурского теократического государства Йэттишар, созданного в ходе мусульманского восстания уйгуров и дунган Синьцзяна в 60-70-х гг. XIX в., важная, но недостаточно изученная страница истории международных отношений в Центральной Азии.

Возникновение исламского государства в зоне соприкосновения интересов трех империй - России, Китая и Великобритании резко изменило политическую ситуацию в регионе. Оказавшись в новых условиях, Российская империя, стремившаяся к скорейшему укреплению своих позиций в Казахстане и Средней Азии, должна была определить свои внешнеполитические приоритеты. В итоге Россия заняла позицию нейтралитета в китайско-мусульманском противостоянии. При этом ситуация в пограничных районах так и не обрела стабильности. Новые соседи повели себя весьма вызывающе, что приковывало к себе внимание администрации Туркестанского края и постоянно вызывало новые отвлечения сил и средств. В то же время отношения с Китаем осложнились, при этом было необходимо разрешить проблему восстановления торгово-экономических связей и пограничного спора.

Таким образом, российская сторона была вынуждена отходить от строгого соблюдения позиции невмешательства в китайско-кашгарские дела. В итоге в основу налаживания отношений с новым мусульманским государством российским правительством были положены исключительно торгово-экономические интересы. От политических контактов, а тем более от официального признания государства Йэттишар - главной цели внешней политики Якуб-бека, правительство Российской империи категорически отказалось. Одним из значимых этапов формирования более или менее прозрачной конфигурации отношений с непредсказуемым правителем вновь созданного государственного образования является заключение русско-кашгарского торгового договора 1872 г.
Relations between Russia and the Uighur theocratic state Yettishar, created during the Muslim rebellion of the Uigurs and the Dungans of Xinjiang in the 60-70s of the $19^{\text {th }}$ century, is important but insufficiently studied page of the history of international relations in Central Asia.

The emergence of the Islamic state in the zone of contiguity of interests of the three empires - Russia, China and Great Britain - dramatically changed the political situation in the region. Faced with the new conditions, the Russian Empire, striving for the earliest possible strengthening of its positions in Kazakhstan and Central Asia, had to determine its foreign political priorities.

As a result, Russia took a noninterference position in the Sino-Muslim confrontation. At the same time, the situation in the border areas has not gained stability. The new neighbors demonstrated a defiant attitude, which attracted the attention of the administration of the Turkestan region and constantly provoked new distractions of forces and means. At the same time, relations with China got complicated, but at the same time it was necessary to solve the problem of restoring regional trade and economic ties and solve the border issue.

One of the significant stages in the development of a more or less transparent configuration of relations with the unpredictable governor of the newly created state formation is the conclusion of the Russian-Kashgar trade agreement of 1872 . 
Ключевые слова: Йэттишар, Восточный Туркестан, Кашгар, Якуб-бек, восстание, граница, генерал-губернатор К.П. Кауфман, дипломатическая миссия, посланник А.В. Каульбарс, военная экспедиция.

\section{DOI 10.14258/izvasu(2019)6-12}

Возникновение в 60-х гг. XIX в. на территории Синьцзяна ряда государственных образований, непредсказуемость действий их правителей создали для пограничных российских властей, занятых обустройством новых владений империи в Средней Азии и Казахстане, ряд серьезных проблем [1, с. 26-27]. Практически была прекращена ставшая за длительное время традиционной торговля с Западным Китаем и внутренними провинциями Цинской империи, прекратилось движение караванов. Это неблагоприятно отразилось на положении в пограничных городах, экономика которых в определенной мере была ориентирована на рынки соседнего региона. Ситуация становится объектом пристального внимания английской колониальной администрации Индии, постоянного соперника русских властей в борьбе за региональные сферы влияния. С целью изучения военно-политического положения и подготовки условий для включения новых мусульманских ханств, недружелюбно настроенных по отношению к России, в сферу своего влияния, на территорию бывшего китайского наместничества направляется ряд тайных миссий из Британской Индии. Проявляет интерес к происходящим событиям и Турция. Цинское правительство, фактически утратившее контроль над Синьцзяном и не получившее реальной поддержки со стороны России, не могло принять адекватных мер для восстановления своей власти, так как было вынуждено сконцентрировать усилия для подавления восстаний во внутренних районах Китая.

22 июня 1871 г. русские войска, после предварительного уведомления китайских властей, заняли Илийский край и ликвидировали Кульджинский султанат [2; 3, с. 19]. Правитель Иээтишара ${ }^{1}$ Якуб-бек ${ }^{2}$ был лишен возможности присоединить к своим владениям новые территории на этом направлении и одновременно потерял потенциального союзника в лице бывшего владетеля султаната Аляхана Абиля Оглы. Характеризуя позицию кашгарско-
Key words: Yettishar, East Turkestan, Kashgar, Yakub-bek, rebellion, border, Governor-General K.P. Kaufman, diplomatic mission, envoy A.V. Kaulbars, military expedition. го правителя, генерал-губернатор Туркестанского края К.П. Кауфман писал директору Азиатского департамента: «После удачного, как кажется, похода на Урумчи, он на обратном пути, остановился в Аксу и готовился к обороне в ожидании нашего прихода. Когда же он увидел, что мы, по занятии Кульджи, не двинулись дальше, он успокоился и теперь заговорил другим тоном» [4, л. 53].

В период подготовки и проведения силовой операции в Кульдже русская пограничная администрация была вынуждена прогнозировать развитие ситуации в регионе и с учетом событий корректировать свою деятельность. В этой ситуации стала актуальной проблема установления бесконфликтных временных отношений с Йттишаром.

21 июня 1871 г. генерал-губернатор Туркестанского края К.П. Кауфман предоставил военному министру записку «Вопросы, касающиеся нашей политики в Средней Азии и подлежащие обсуждению», в которой содержался ряд предположений о перспективах развития русско-кашгарских контактов и подходов к разрешению ключевых вопросов. К.П. Кауфман обоснованно предполагал, что в ходе выстраивания отношений с правителем Йэттишара сначала необходимо было решить проблему восстановления торговли и только после этого переходить к пограничному вопросу.

Стремясь компенсировать потерю Кульджи, Якуб-бек попытался установить более тесные контакты с Кокандом и Бухарой с целью создания антироссийского военно-политического союза. Однако предпринятые попытки не принесли ожидаемого результата, напротив, обострили взаимоотношения с российской стороной. Положение осложнилось, когда К.П. Кауфману стало известно содержание переписки между ханом Коканда Худояром и кашгарским правителем. Под различными предлогами Якуб-бек пытался убедить кокандского хана в необходимости борьбы с русскими властями. Бадаулет активизировал панисламистскую про-

\footnotetext{
${ }^{1}$ Йэтишар - уйгур. «йәттә» семь, «шәһәр» город, «йәттә шәһәр» - «Семиградье», города центры семи округов: Кашгар, Хотан, Куча, Аксу, Курля, Янги гиссар, Яркенд. Д.А. Исиев определял Йэттишар как уйгурское государство.

${ }^{2}$ Мухаммед Якуб-бек (1820-1877), правитель государства Йэттишар («Семиградье») в Восточном Туркестане, таджик из Пскента (Кокандское ханство), правитель Чиназа, с 1851 г. бек крепости Ак-мечеть, участник неудачного заговора против кокандского Худояр-хана, в 1865 г. послан в Кашгар помощником Бузрук-ходжи - ставленника кокандского хана, который возглавил повстанческие силы в Кашгаре после восстания 1864 г., узурпировал власть в Кашгаре, после чего начал завоевание городов Восточного Туркестана, в 1870 г. провозгласил создание самостоятельного государства и стал его правителем, имел титулы Аталик-гази, Бадаулет («Защитник веры и счастливец»). В состав государства вошла вся территория современного Синьцзяна (за исключением Илийского края).
} 
паганду на сопредельных территориях и не оставлял замыслов о расширении подконтрольных ему земель на граничных с российскими владениями пограничных участках. В ответ генерал-губернатор Туркестанского края предупредил кашгарского $^{3}$ правителя о готовности применить против него военную силу [5, л. 20-25об.]. При этом силовой вариант решения проблемы содержал в себе ряд сложностей. Так, в случае занятия русскими войсками Йэттишара пришлось бы оставлять военные гарнизоны, при этом нужно было решать задачи по обеспечению постоянной связи с ними и материально технического снабжения. Это было трудно осуществить в силу естественно-географических условий местности и причин финансового характера. Формирование новой системы управления краем и организация местных административных аппаратов также было довольно сложным делом. Высока была вероятность возникновения волнений в среде симпатизировавшего Якуб-беку мусульманского населения прилегающих районов Средней Азии и Казахстана. Таким образом, более предпочтительным выглядел вариант налаживания с ним торговых отношений. В этом случае необходимо было найти невоенный или комбинированный способ решения проблемы, без вторжения на кашгарскую территорию.

28 февраля 1872 г. туркестанский генерал губернатор К.П. Кауфман получил от Бадаулета письмо с просьбой прислать к нему доверенное лицо [6, с. 51]. В резолюции генерал-губернатор Туркестанского края писал: «Остается, следовательно... способ, которого очевидно лучше достигнуть мирным путем, если то можно, и потому благоразумие требует испытать его всеми мерами и прибегнуть к оружию должно тогда, когда можно получить убеждение, что никакие другие меры, кроме войны, не могут дать желательных результатов» [7, л. 5-6]. Якуб-бек, озабоченный резкими высказываниями туркестанского генерал-губернатора, обеспокоенный непрекращающейся борьбой с урумчинскими дунганами и возможностью китайского военного реванша, вынужден был идти на уступки.
После консультаций с Министерством иностранных дел и Военным министерством К.П. Кауфман решает использовать этот шанс и направляет в Йэттишар миссию во главе с подполковником Главного штаба А.В. Каульбарсом ${ }^{4}$ с целью заключения с Якуб-беком торгового договора. В письме к Якуб-беку, отправленному из Ташкента 5 апреля 1872 г., туркестанский генерал-губернатор писал: «Письмо Ваше, написанное в ответ на мое письмо 13 октября минувшего года, я получил и со вниманием прочел. Оно мне не выяснило еще Ваших намерений, ... я вслед за сим отправляю к Вам почетное посольство из доверенных лиц, главе которого барону Каульбарсу поручено будет объяснить Вам предлагаемые мною условия прочной дружбы между владениями Джитышара и могущественной Россией. Приложением к этим условиям своей печати, в знак утверждения их и принятия к руководству, Вы докажете свою готовность вступить в близкие соседские отношения с нами, другого нет пути установлению между нами дружбы» [7, л. 37].

Следующее послание имело тон ультиматума: «...глава посольства, Генерального штаба капитан барон Каульбарс, передаст Вам мое желание вступить в прочные дружеские с Вами отношения, как с правителем Джитышара... У меня одна цель - жить в мире с соседями... Вам предстоит теперь выбирать одно из двух: мир или вражду» [7, л. 57]. Правитель Коканда Худояр-хан выступил в качестве посредника и отправил в Кашгарию трех посланцев с письмами от себя и от туркестанского генерал-губернатора. Однако эффект оказался прямо противоположный ожидаемому. Бадаулет не только не принял посланцев, но и угрожал прервать контакты с русскими властями, если они не откажутся от услуг кокандцев [7, л. 30-31].

Далее, под предлогом проведения дорожностроительных работ на границу с Йэттишаром были выдвинуты русские военные отряды, усилены гарнизоны пограничных укреплений. В письме военному министру Д.А. Милютину туркестанский генерал-губернатор К.П. Кауфман отмечал: «...на случай, если Якуб-бек окончательно откажет-

\footnotetext{
${ }^{3}$ Кашгария, или Восточный (Китайский) Туркестан, Алтышар - южная часть провинции Синьцзян в Западном Китае, географически точно не совпадала с территорией Йэттишара, однако в трудах военных исследователей 60-80-х гг. XIX в. (А.Н. Куропаткин, Л.Г. Корнилов и др.) использовался в качестве общеупотребительного названия владений Якуб-бека.

${ }^{4}$ А.В. Каульбарс (1844-1929), родился в Санкт Петербурге. Закончил школу гвардейских юнкеров, прошел курс наук в Академии Генерального штаба. По распределению был направлен для прохождения службы в Туркестанский край. Службу проходил в гарнизонных штабах Семипалатинска, Верного, Ташкента. Участвовал в Хивинском походе и в нескольких военно-научных экспедициях на Тянь-Шань, в Прииссыкулье, где основал г. Каракол, позднее Пржевальск. Являлся участником ряда дипломатических миссий. В 1872 г. возглавлял российское посольство в Йэттишар. В 1873 г., находясь в составе Аму-Дарьинской экспедиции, обнаружил судоходный путь из Аральского моря. Получил звание генерала от кавалерии, в течение 10 лет был военным министром болгарского княжества. Командовал дивизиями в Китае и Маньчжурии. Являлся одним из создателей российской авиации. Во время Первой мировой войны был посланником России во Франции.
} 
ся согласиться на предлагаемое ему мною через посредство посольства соглашение, стать до известной степени угрожающее относительно Алтышара положение» [7, л. 50].

15 апреля 1872 г. русская миссия, направленная в Йэтишар во главе с подполковником Главного штаба А.В. Каульбарсом, покинула Ташкент. Генералгубернатор Туркестанского края К.П. Кауфман дал посланнику ряд словесных указаний: барон должен был внушить Якуб-беку мысль о том, что «... не Россия в нем нуждается, а он в России, принятием и утверждением предлагаемых ему условий о свободной торговле он вступает на единственный путь, ведущий к дружбе с Россией, помимо принятия этих условий не может быть и речи о дружбе» [7, л. 41].

Во второй половине апреля 1872 г. российская миссия прибыла в Йэттишар. В начале мая в г. ЯнгиГиссаре произошла первая встреча Якуб-бека и русского посланника, в ходе которой состоялись предварительные переговоры. Барон Каульбарс так описывает первую встречу с Бадаулетом: «В комнате, совершенно один, на ковре сидел не очень рослый, но довольно плотный человек, правильные черты лица его освещались умным выражением и некоторым блеском глаз, но в этом лице нельзя было прочесть чего либо особенного... То был правитель Джетышара, гроза Восточного Туркестана» [7, л. 57]. Кашгарский правитель не смог скрыть под маской напускного равнодушия своего удовлетворения от посещения его владений представителями Российской империи. Так, при возникшей заминке на приеме он сказал: «...садитесь где хотите, на мое колено, на мою грудь, вы гости, посланные богом» [7, л. 71]. Однако после обмена традиционными любезностями и обоюдных заверений в дружеских намерениях на следующей аудиенции у Бадаулета, которая носила закрытый характер [7, л. 73], в ходе диалога между русским посланником и кашгарским владетелем возникли определенные осложнения. Якуб-бек, ознакомившись с условиями договора, высказал ряд претензий. Признавая необходимость налаживания с Россией торговых отношений, он предложил вариант постепенного развития торговли, в качестве причины называя имеющее место недоверие кашгарцев к русским купцам. В ответ на это А.В. Каульбарс заявил, что договор о торговых отношениях является главным условием дальнейшего развития взаимоотношений между Йэтишаром и Россией. Далее кашгарский владетель попытался увязать подписание договора с получением согласия российской стороны на посылку своего представителя ко двору российского императора: «Обещайте мне, что мой посланник теперь поедет с Вами в Ташкент, а оттуда к Великому Ак Баше, тогда генерал-губернатор и Ак Баша будут судить обо мне по словам моего собственного человека»
[7, л. 75об.]. Ответ русского посланника относительно поездки в Ташкент был положительным, по поводу дальнейшего следования кашгарского посланника в Петербург глава русской миссии предпочел умолчать. После чего Якуб-бек, приведя в пример «покровительственную» политику английских колониальных властей в отношении индийских мусульман, высказал просьбу о получении покровительства со стороны туркестанского генерал губернатора: «Я никогда ничего дурного против Вас не делал, считаю за честь, что ко мне приехало русское посольство, поэтому я теперь прошу такого же покровительства туркестанского генерал губернатора» [7, л. 75об.]. А.В. Каульбарс согласился принять и это условие, но только после подписания Бадаулетом всех пунктов договора. Однако кашгарский правитель не остановился на этом и продолжал высказывать все новые претензии, искусственно затягивая переговорный процесс. Якуб-бек нашел неприемлемым для себя и своих подданных условие договора об организации транзитной торговли и создании «караван сараев» в городах Йэтишара, посчитав, что последние станут центрами русского влияния. Глава российской миссии пояснил, что транзитная торговля ведется на территории многих стран и не приносит неудобств населению, а купеческие предприятия будут способствовать укреплению чисто торговых интересов с выгодой для обеих сторон. Прояснив для себя, таким образом, позицию России и убедившись в твердости намерений русского посланника, Якуб-бек предложил А.В. Каульбарсу составить текст соглашения с последующим его публичным оглашением в Ташкенте. На эту просьбу кашгарского правителя также был дан положительный ответ, более того, русский посланник заверил Бадаулета в том, что текст договора будет представлен «Белому Царю» [7, л. 77об.]. При очередной встрече главы русской миссии и правителя Йэттишара Бадаулет согласился подписать проект договора, однако отложил саму процедуру подписания на неопределенный срок. Кашгарский правитель пытался продлить пребывание русской миссии в Кашгаре, чтобы использовать этот факт для поднятия собственного авторитета в глазах народа. С другой стороны, Якуб-бек стремился создать стимул для активизации англичан в Восточном Туркестане, что и подтвердили дальнейшие события [8; 9].

Результатом этих достаточно сложных переговоров стало подписание русско-кашгарского торгового договора 21 мая 1872 г. Согласно его условиям российские купцы должны были получить право на беспрепятственную торговлю на территории Йэттишара. Подданные Якуб-бека, в свою очередь, могли иметь право торговли на всей территории Российской империи. Бадаулет брал на себя обязательство обеспечивать личную и имущественную 
безопасность российских купцов, а также их караванов. Купцам обеих сторон разрешалось содержать в городах своих торговых представителей - караван-баши. Сумма торговых пошлин должна была составлять не более двух с половиной процентов стоимости всего товара. Кашгарские и российские купцы получали право проезжать через территорию обоих государств по своим коммерческим делам в третьи страны.

Заключение договора с Якуб-беком явилось значительным успехом российской дипломатии. Правительство Российской империи было удовлетворено действиями К.П. Кауфмана и А.В. Каульбарса [10, л. 198]. Туркестанский генерал губернатор, касаясь результатов удачно завершившейся деятельности русской миссии в Йэттишаре, писал 11 августа 1872 г. военному министру Д.М. Милютину: «...стремление наше открыть мирным путем Восточный Туркестан для нашей торговли привело к желанной цели... Самый факт, что Якуб-бек принял предложенные ему условия, прежде чем испытать на себе силу нашего победоносного оружия, доказывает, что нравственный перевес наш в Средней Азии благодаря твердости нашей политики и прежним военным успехам, вполне соответствует достоинству и силе России. Не менее важно и то обстоятельство, что теперь по заключении с Якуб-беком другого договора, мы на первое время, а может быть, и навсегда, избавились от угрожавшей нам необходимости идти походом на Кашгар» [7, л. 92-93].

Российская сторона, официально не признавая Йэтишар в качестве независимого государства, сумела добиться подписания выгодного для себя договора без каких-либо политических уступок. В случае прямого нарушения условий договора правитель Йэттишара нес ответственность как глава государства со всеми вытекающими из этого последствиями. Со стороны Российской империи ответственность за соблюдение выполнения пунктов подписанного соглашения возлагалась на туркестанского генерал губернатора К.П. Кауфмана. Таким образом, с юридической точки зрения выигрыш оставался за Россией.

В то же время в торговых отношениях между Россией и Йэттишаром заметных изменений в по- ложительную сторону не произошло. Якуб-бек, воспользовавшись благоприятными для него обстоятельствами, организовал отправку нескольких караванов в российские пределы, стремясь в короткий срок получить для себя максимальную выгоду. Российская торговля в Кашгарии [11, с.142], в нарушение условий договора, как и прежде, подвергалась постоянным ограничениям и притеснениям со стороны властей Йттишара [6, с. 3]. Опасаясь реакции российских властей на открытое игнорирование условий заключенного торгового договора, Якуб-бек направил в Ташкент специальную миссию. Однако и в этом случае после ташкентских переговоров с кашгарскими посланцами каких-либо существенных изменений в отношении российских купцов со стороны властей Йэтишара не произошло [6, с. 53].

Бадаулет, подписывая торговый договор, предполагал извлечь из этого прежде всего политическую выгоду, стремясь представить его как официальное признание российской стороной государства Йэтишар. Добившись определенных гарантий безопасности, он начал активные военные действия против Дунганского союза городов, нанес ему окончательное поражение, присоединил его территорию к своим владениям и начал активно сотрудничать с англичанами, заключив с ними 2 февраля 1874 г. торговый договор с рядом преимуществ политического характера [4, л. 49-53].

На наш взгляд, результаты миссии и подписание русско-кашгарского торгового договора в 1872 г. принесли временный положительный эффект. На определенном этапе в отношениях между Россией и Кашгарией были сняты острые противоречия. Однако приоритет во внешней политике Российской империи оставался за Китаем, а так как Петербург признавал приоритет Китайской империи над Синьцзяном, отношения с Йэттишаром объективно не могли выйти на более высокий уровень [12, с. 100]. Таким образом, собственно сам процесс подписания договора носил формальный характер, обе заинтересованные стороны, помимо официально заявленных, преследовали и иные цели, которых в определенной мере они достигли $[12$, c. 101$]$.

\section{Библиографический список}

1. Исиев Д.А. Уйгурское государство Йэттишар. М., 1981.

2. Моисеев В.А. Россия и Китай в Центральной Азии (вторая половина XIX в. - 1917 г.). URL: http://perviydoc. $\mathrm{ru} / \mathrm{v} 23446 /$ моисеевв.а.россияикитай в центральной_ азии? page $=4$; https://web.archive.org/web/20071112013058/ http://new.hist.asu.ru/biblio/ruskit/01.html (дата обращения: 04.07.2019).

3. Стрельбицкий И. Земельные приобретения России в царствование императора Александра II-го, с 1865 по 1881 год. СПб., 1881. 
4. Архив внешней политики Российской империи. Ф. СПб., Главный архив. 1-9. 1865-1878. Оп. 8. Д. 14.

5. Центральный государственный архив Республики Казахстан. Ф. 44. Оп. 1. Д. 5649.

6. Кожирова С.Б. Российско-китайская торговля в Центральной Азии (вторая половина XIX - начало ХХ вв.). Астана, 2000.

7. Российский государственный военно-исторический архив. Ф. ВУА. Д. 6823.

8. Гарбузарова Е.Г. Восточный Туркестан в спектре геополитических интересов России и Великобритании в XIX веке. URL: http://elibrary.auca.kg/bitstream/123456789/323/1/ Garbuzarova_2009_2.pdf (дата обращения: 04.07.2019).
9. Дубровская Д.В. Судьба Синьцзяна. Обретение Китаем «Новой границы» в конце XIX в. URL: http://www. tinlib.ru/istorija/sudba_sinczjana/p1.php (дата обращения: 04.07.2019)

10. Центральный государственный архив Республики Узбекистан. Ф. И-715. Оп. 1. Д. 52.

11. Шкунов В.Н. Синьцзян в системе российско-китайской торговли в XIX в. // Известия Самарского научного центра Российской академии наук. Т. 19, № 3. 2017.

12. Моисеев С.В. Взаимоотношения России и уйгурского государства Йэттишар (1864-1877 гг.). Барнаул, 2006. 